\title{
CONTRIBUTION TO THE STUDY OF GRAVE FINDS OF WEAPONS AND MILITARY EQUIPMENT FROM THE ROMAN PERIOD ON THE TERRITORY OF SERBIA
}

\author{
Milan Savić \\ Kuršumlija \\ e-mail: milan.savic93@gmail.com $\mid$ Review article \\ Received: 15. 6. 2020. UDC: 904:726.821"652"(497.11) \\ Accepted: 4. 9. 2020. 904:623.44"652"(497.11)
}

\begin{abstract}
The following text analyses finds of weapons and military equipment in funerary contexts from the ancient Roman period on the territory of Serbia. This paper aims at determining the period and the sites on the territory of Serbia during the Roman times where the phenomenon of burying military equipment in funerary contexts has been recorded, and presenting the data that archaeology comes across by analysing archaeological finds of this type as well as pointing out the complexity and problems of interpreting "warrior" or "military" graves. An analysis of the existing material has shown that this funerary custom was practiced during the entire period of Roman domination. The paper singles out several interesting grave units that pose several new questions in the field of considering grave finds of weapons from the ancient Roman period.
\end{abstract}

Keywords: grave finds of weapons, grave contexts, Roman period, funerary rite, warrior, soldier

\section{Introduction}

The study of grave contexts is a very important topic in archaeology, given that necropoles are one of the main spheres of life in which a community defines its identities, those that connect them, but also those that distinguish them from others (Mattingly 2011, 226). Therefore, graves can be viewed as private spaces of personal expression, and at the same time, as a social arena of the dead and the living (Pearson 2003, 28). By analysing grave forms and grave goods, which are mediators in burial practices, we try to understand their value in socially constructed contexts. The obtained data are used in an attempt to reconstruct funerary practices, the social structure of the community, social ties, identity, age, gender, and perception of their influence on the organization of a necropolis (Cvjetićanin 2016, 719, Pearce 2017, 4).

It must be borne in mind that grave goods represent a kind of a rearrangement of the entire system, which implies placing everyday objects in a new context (Cvjetićanin 2016, 721). That is why their symbolism is mostly unknown 
today; still, it could have been quite obvious to the participants and organizers of a funeral (Korać and Golubović 2009, 527), while the logic of a funeral act that created archaeological records also remains mostly unclear (Morris 1992, 108).

When it comes to the Roman period, special attention is paid to the finds of weapons and military equipment in funerary contexts, on the basis of which "warrior" or "military" graves are defined. It is a complex funerary phenomenon that is interpreted differently in the professional literature. Historical sources provide little information about military burials from the Roman period. It is only known that soldiers who would die honourably on the battlefield were buried where possible - in mass graves or cremated (funus militare) (Toynbee 1971, 55, Retief and Cilliers 2010, 136). In his work Epitoma Rei Militaris, Flavius Vegetius Renatus states that soldiers had to contribute half of their income "under the flag". Part of that money served, among other things, as a mutual fund to cover the costs of burying deceased soldiers (Vegetius II, XVI). However, these written sources do not mention placing weapons as grave goods.

The aim of this paper is to determine the period and sites on the territory of Serbia during the Roman domination where the phenomenon of placing military equipment in funerary contexts has been recorded and to present the data that archaeology comes across by analysing mobile finds of this kind and pointing out the complexity and problems of interpretation. One of the goals is to relativize the concept of "warrior" or "military" graves, which can also be defined in several ways.

\section{The notion of a "warrior" or "military" grave in Roman archaeology}

In an attempt to explain the term "warrior" or "soldier" grave as precisely as possible, it is necessary to analyse these two terms, which we encounter equally often in the Serbian language, as synonyms ${ }^{1}$.

\footnotetext{
${ }^{1}$ In Serbian, the term soldier (vojnik) means a person who is a member of the armed forces intended for the defence of a country; a person who serves in the army, a conscript during his military service, as well as the reserve of the armed forces, in case of war (Вујанић et al. 2011, 155). He belongs to the military - a state institution and is obliged to act according to the rules of the military law and ethics (Гроздић, Кузмановић and Николић 2011). The term warrior (ratnik) is a term with a narrower sense and means a person who is a participant in a war (Вујанић et al. 2011, 1119). In addition to the terms warrior and soldier, Serbian language has other synonyms: vojniče, vojničar, borac, bojovnik, borač, borilac, boritelj, bojdžija, bojac, ustanik, megdandžija, etc. (Стевановић et al. 1962, 65). On this occasion, I would like to thank the director of the National Library from Kuršumlija, Nebojša Gašić, who helped me find adequate dictionaries of terms and synonyms of the Serbian language. In the communities of the past, the term soldier or warrior could have had different meanings. For the concept of warriors of the Late La Tène period see: Pernet 2010, for the Ancient Greece: Kagan and Viggiano 2013, Lloyd 2014, the ancient Roman period: Santosuosso 1997, Phang 2008. During the period of the Roman Empire, certain universal and obligatory frameworks of military life and the army as an institution were undoubtedly created, which have remained almost unchanged in modern societies; life in the barracks, order of advancement in the army, military trumpet, order of duty, morning report, right to a pension, and even the battlefield as a stage on which the conflict between two armies takes place (Карије 2006, 119).
} 
Namely, considering different archaeological material from the ancient Roman period, a "warrior" or "military" grave can be defined in several ways. First of all, through epigraphic monuments - grave stelas with inscriptions that can provide us with personal and professional information about the deceased. However, locating a "warrior" or "military" grave on the basis of epigraphic monuments is very difficult and limited, since stelas are rarely found in situ.

On the other hand, graves of this type can be determined on the basis of the finds of weapons and military equipment, which were put along the deceased as grave goods. Tempting as it is, it is not always possible to claim with certainty that it is a grave of a "warrior" or a "soldier" based on these finds for the simple reason that weapons can be found in graves of women and children too. Such contexts clearly indicate that it was not always a burial of military personnel, and one should be especially careful when interpreting such grave units, as suggested by the authors who process grave finds of weapons of ancient Greek warriors (Lloyd 2014, 2).

However, grave goods can be interpreted in other ways, i.e., a specific symbolic value of these objects can be assumed. Although it is challenging to determine a symbolic value, it is possible to assume that they ended up in graves as inheritance from a husband, father, or some other family member, and that they could be an indicator of the social class of a deceased. It should be added that, for example, one set of spurs in graves (Ercegović 1961, 125-137) (List 1) of the La Tène epoch could be interpreted as a possible sign of belonging to the equestrian class (Филиповић 2009, 163-188), which was reserved for members of tribal aristocracy in prehistoric communities.

Finds of military equipment in graves can also be a result of a deliberate selection by the community conducting a funeral. Thus, Czarnecka assumes that finds of a scabbard without a sword indicate a deliberate choice of grave goods, which served as a replacement (pars pro toto) (Czarnecka 2013, 166). We should not lose sight of graves with weapons, in which no remains of human bones were found, or anthropological remains in them were very scarce. This is the case of a tomb, $50 \mathrm{~m}$ away from the ramparts of Felix Romuliana, which according to the author (Bülow von 2013), may represent a cenotaph (List 31).

However, it should be said that finds of weapons in graves do not have to be exclusively parts of grave goods, but could have entered such a context in a completely different way. Thus, in some cases, arrows can be found buried in bones or among the bones of the deceased, indicating the direct cause of death. For the time being, two such examples from the Roman period have been confirmed in the area of today's Serbia; one is a Late Antique grave 123 at the ne- 
cropolis of Slog, in which an arrow was found buried among the rib bones of the deceased (Petković et al. 2005, 43, Pl XI/G. 125) (List 37), while a three-edged arrow was also found buried deeply in the right femur of the deceased in grave 152 at the Viminacium necropolis Pirivoj (Golubović, Mrđić, and Scott Speal 2007, Fig. 15) (List 54). Care should also be taken when interpreting such examples because the deceased with wounds or those who died a violent death did not necessarily have to be military personnel, but also any other person who may have died in combat. ${ }^{2}$

It should be noted that in the Serbian scientific literature, graves of Roman soldiers or even presumed commanders of the Roman regular army are defined only on the basis of the findings of Late Antique cruciform fibulae and belt buckles (Petković et al. 2005, 328-329, Петковић 2010, 186-187, Fig. 158, 160).

\section{Finds of weapons in graves of the Central Balkan tribes}

At this point it is very important to look at prehistoric graves of the Central Balkan tribes with findings of weapons and military equipment. From long before the arrival of the Romans, such funerary rites have been recorded in the area of today's Serbia and a larger part of the Balkan Peninsula during the Iron Age. Burial practices of such type have been registered in areas that were presumably ruled by ancient Celts, i.e., Scordisci, Taurisci, Karni, Autariats, Dardani, Thracians, and others. With this in mind, the territory of today's Serbia is even more interesting, since such funerary rites and ceremonies can be considered even before the establishment of the Roman domination, within numerous prehistoric communities.

As interesting grave units from the Iron Age in the Balkans, we should certainly mention the so-called "Princely Graves" within the Glasinac culture. Such graves are distinguished by the type and quantity of grave goods, which largely include finds of weapons of autochthonous and Greek origin. These are the graves of cremated or inhumed deceased individuals under tumuli, in which weapons can be found from the phase IVa $(800-750 / 725 \mathrm{BC})$ to the phase Va (500/475-350 BC) (Palavestra 1997, 316-319). So far, numerous interpretations of these grave units have been offered in professional literature (Benac and Čović 1957, 31, Бабић 2004, 102).

Let us also look at the period of the Late Iron Age, which is not only chronologically before the establishment of the Roman rule, but also because some funerary practices of the La Tène period left traces and have been recorded

\footnotetext{
${ }^{2}$ See the paper: Novak 2013, 347-355 on anthropological analyses of skeletons from the ancient Roman period, with traces of injuries caused by cold weapons.
} 
on findings from the Roman Empire period. Numerous autochthonous tribes, which inhabited parts of today's Serbia, Croatia, Slovenia (Scordisci, Taurisci, Karni) are associated with a funerary ritual which meant that swords, spears, and other parts of military equipment were deformed, bent, and partially destroyed and then placed in the graves of the deceased (Todorovic 1968). It is assumed that those were graves in which members of the warrior elite were buried and that weapons in the form of grave goods could testify to their prominent position in the community (Dizdar, Šoštarić and Jelinčić 2003, Dizdar and Radman-Livaja 2004, Istenič 2013, Tonc, Radman-Livaja and Dizdar 2013, Dizdar and Potrebica 2014, Dizdar and Radman-Livaja 2015).

\section{Is placing of weapons in graves a funerary custom of the Romans or not?}

Grave inventory in the form of weapons is generally accepted in professional literature as a Germanic custom (Bülow von 2013, 154). The cremation of a deceased with his weapons by Germanic tribes was also mentioned by Tacitus (Tacitus I, 27). However, we should not forget the fact that laying weapons in graves was not typical of all Germanic tribes. For example, the complete absence of weapons and warrior equipment in the graves of deceased male individuals stands out as a trait of East Gothic funerary customs (Милинковић 1998, 55). Germanic funerary customs of placing weapons may also have influenced a number of burial contexts of the Roman period, as many members of the Germanic tribes also served in the Roman army as auxiliaries or federates (foederati).

On the other hand, the appearance of weapons in grave units is usually considered a funerary practice that is not typical of the Romans. Although it was not uncommon for a Roman soldier to be buried with weapons and military equipment, these were sporadic examples. The fact that there are finds of weapons placed in graves during the Roman period should in itself serve as a reason for a careful interpretation of the "users" of weapons, i.e., the individuals found with them (Bishop and Coulston 1993, 33).

The fact that there have been few finds of legionnaire weapons in graves can be partly explained by numerous laws of the Roman state, which implied severe penalties for losing weapons (Phang 2008, 83). A soldier was personally responsible even when it came to repairing his equipment (Nicolay 2007, 166-167). It is known that Roman soldiers, after serving their military service, decommissioned or returned their weapons to the Roman state (MacMullen 1960, 23). Certain finds of early imperial helmets, on which several different inscriptions have been noted, which mentioning different names of legionnaires and units, indicate that the weapons had indeed been inherited and handed over to other recruits. Sev- 
eral different inscriptions were registered on the neck-shield of an early imperial helmet from the river Sava near the village of Rugvica in Croatia (Radman-Livaja and Dizdar 2010,49), and one specimen taken from the river Thames in Great Britain (Olson 2013, 12, Fig. 2). The inscriptions on these helmets show that the equipment could have been inherited even among soldiers of different units, although a much more common case was inheritance within the same unit (Vujović 1998, 11).

However, it would seem that decommissioning weapons and returning them to the Roman state hadn't been always respected, although there were finds of Roman gladius, cingulum, pilum, and pugio in some graves, sometimes outside the Empire, even in southern Scandinavia, which indicates that their owners may have belonged to different ethnic groups (Grane 2008, 70, Fig. 4, Jensen 2013, 177-182). Gladius finds were also discovered in graves of cremated soldiers from the end of the old era - the beginning of the new era, at the site of Tribanjska Draga (Radman-Livaja 2010, 257), Sveta Trojica near Starigrad Paklenica (Tonc, Radman-Livaja and Dizdar 2013, Fig. 2, 4), Ilok in Croatia (Dizdar and RadmanLivaja 2012, 219, Fig. 9), as well as at the sites of Idrija near Bača, Bobovk near Kranj, Smolenja Vas in Slovenia (Istenič 2013, 23-35, Fig. 4, 5, 7, 8, 9) ${ }^{3}$. Parts of the legionary body armour - laminated armour (lorica segmentata) were recorded in a grave of a cremated individual from the $1^{\text {st }}$ - beginning of the $2^{\text {nd }}$ century at the necropolis of Mala Gorica - 2 near Lederata (Цуњак and Јовановић 2014, 41, 48) (List 5). The top of a pilum was found in grave 11 at the site of Reka near Cerkno in Slovenia (Istenič 2013, 25, Fig. 3/1), and one specimen comes from the site of Požarevac - Bolnica (Piletić 1971, 26, T. IV/17, Vujović 1998, 58, T XVIII/1) (List 57).

Having completed his military service and after returning to the civilian life, a veteran was still able to keep certain parts of his weapons. Such objects would lose their previous war-related and gain a certain "social" role - as symbols of wealth, status, veteran identity, the Roman way of life, but also a kind of personal memorabilia that could evoke various memories from the war days, etc. (Nicolay 2007, 173-174, 177-189, Aarts and Heeren 2017, 144-146). A soldier could also keep a military belt, a symbol of military service that represented his personal property and remained in his possession (Vujović 1998, 162). A soldier's personal property could also contain weapons that he obtained by looting and which he could consider his war trophies ${ }^{4}$. One could only guess what the

\footnotetext{
${ }^{3}$ It is assumed that these graves belong to warriors from Celtic tribes (Taurisci, Carni - territory of Slovenia) who served in the Roman army, retaining their indigenous funerary customs, such as bending swords, but now those of Roman origin - gladius (Dizdar and Radman-Livaja 2012, 210, Istenič 2013).

${ }^{4}$ See papers: Rost and Wilbers-Rost 2013, Rost and Wilbers-Rost 2017 about the importance of archaeological research in locating battlefield locations and on what happened to the dead Roman soldiers after the Battle of the Teutoburg Forest in the year 9 AD.
} 
further fate of the retained parts of weapons was. A soldier could sell them (Pernet 2010,34), bequeath them to his descendants, preserve them as souvenirs, give them as a ritual gift to deities in numerous sanctuaries (Nicolay 2007, 180, 182, Fig. 5.9, 5.10, Aarts and Heeren 2017, 144), and the possibility that he could have been buried with such objects upon his own request should not be ruled out. Even if the placing of weapons in graves is accepted as a funerary custom that was not typical of the Romans, the fact that there are such graves on the territory of the Roman Empire cannot be denied.

\section{Finds of weapons in funerary contexts on the territory of Serbia during the Roman period}

Previous research on Roman necropoles in the area of today's Serbia has brought to light a number of examples of grave weapons. They have been registered in the province of Lower Pannonia, Dalmatia, and Upper Moesia, whose areas were a part of today's territory of Serbia (Map 1). These are graves dating from the period from the $1^{\text {st }}$ up to the middle of the $5^{\text {th }}$ century, so we can say that the placement of weapons in graves of the deceased in this territory was practiced during the entire period of Roman domination. Out of a total of 94 processed grave units, 37 belong to graves of cremated individuals, 31 were inhumed, while, unfortunately, for 26 grave units, there are no more precise data (Graph 1).

Grave weapons were found in various grave forms, so there were burials in ceramic urns (Gardoš, Vranj near Hrtkovci, Čačak), graves in the shape of a well (Sirmium, Singidunum, Viminacium), high-rise graves (Guberevac-Gomilice, Viminacium (Više Grobalja, Pećine), Ljubavica, kod Bresta), tumuli (Magura, Šarkamen), brick or stone grave structures (Viminacium - Pećine, Timacum Minu - Ravna, Mediana - Railway Station Ćele Kula, Horreum Margi, Pirivoj), tombs (Felix Romuliana, Gomolava, Erdevik "Banja Kulina"), stone sarcophagi (Niška Banja), presumed wooden coffins (Beška, Singidunum), while a number of the deceased was freely buried in a grave (Viminacium - Pećine, Gomolava, Beška, Sviloš, Jagodin Mala, Pontes - Trajan's Bridge, Timacum Minus - Ravna, Vranj near Hrtkovci, Singidunum) (Map 1). ${ }^{5}$

The analysis of grave weapons, which was conducted in this paper, clearly shows that there is a significantly higher prevalence of offensive weapons (100)

\footnotetext{
${ }^{5}$ It is difficult to say anything about the tombstones of these graves. Namely, for now, we do not know whether the graves in which the finds of weapons and military equipment were found, have been separated in any way from other graves at the necropoles, from which they do not differ in any significant way. For example, the high-rise graves of Mala Kopašnica-Sase, in which weapons were found, do not differ in quantity and type of grave inventory from other graves of this type.
} 


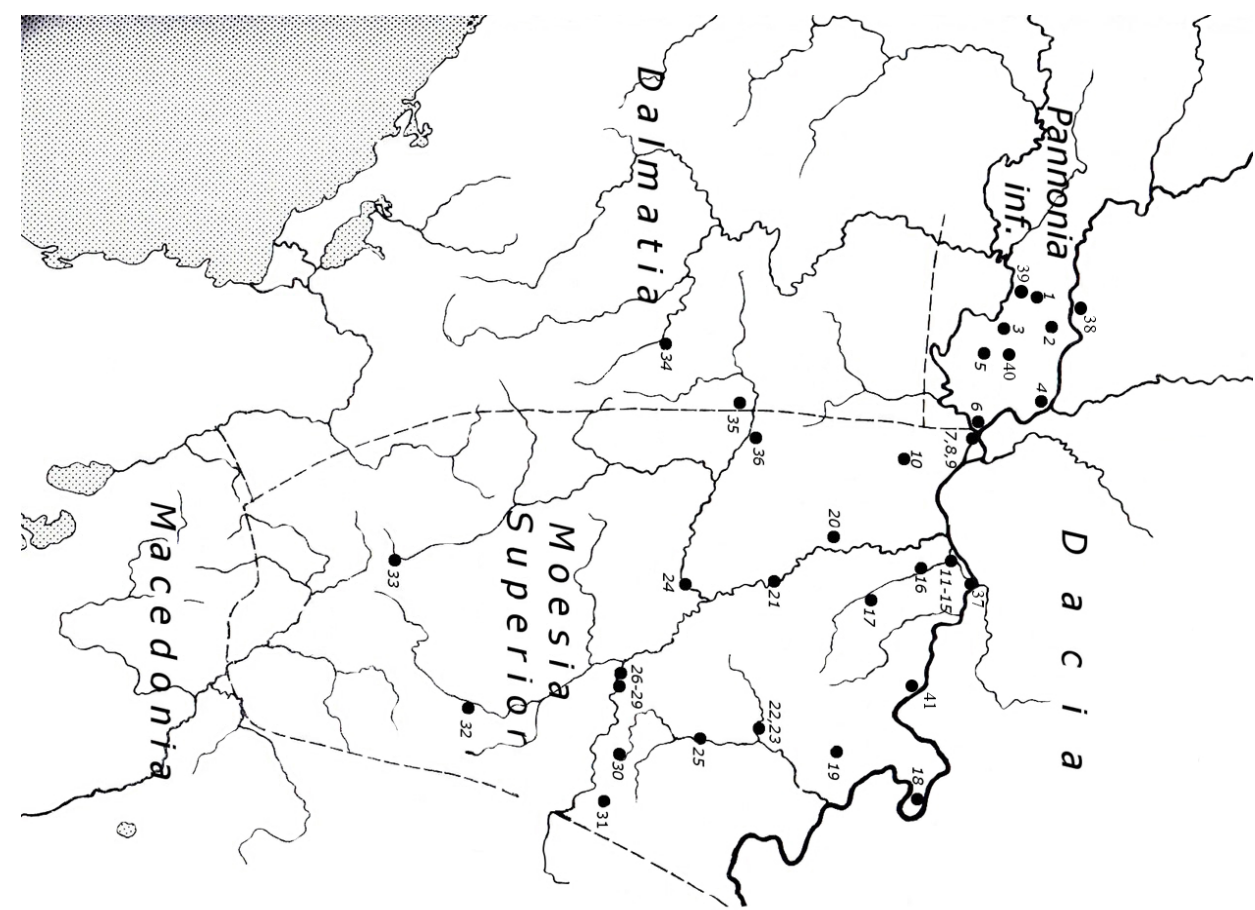

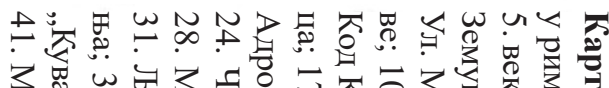

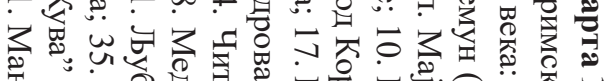

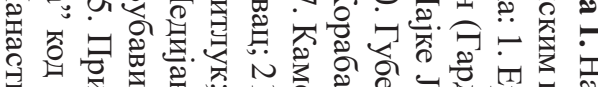

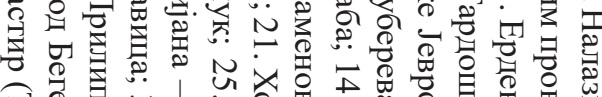
Э马

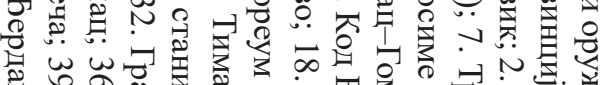

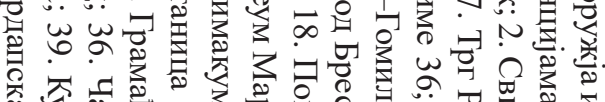

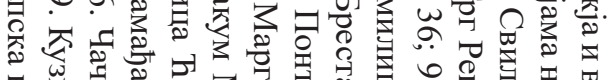

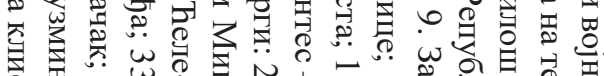

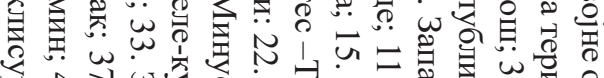

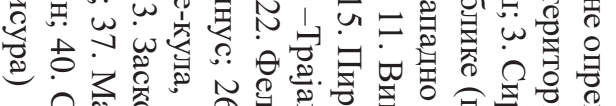

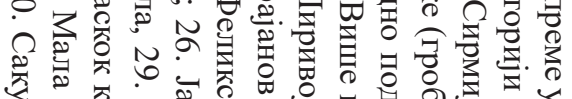

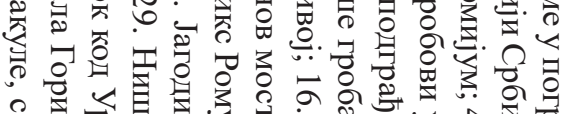

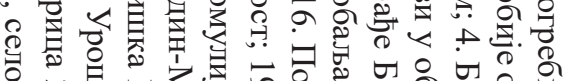

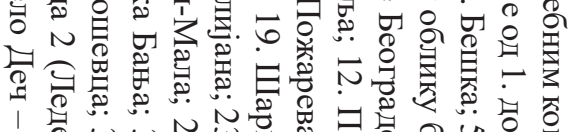

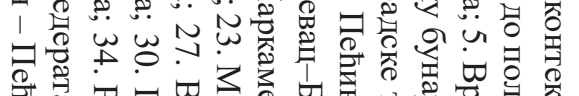

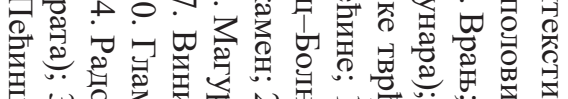

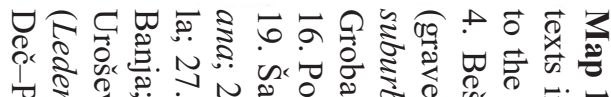

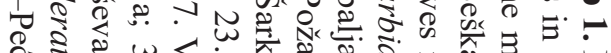
อ: है

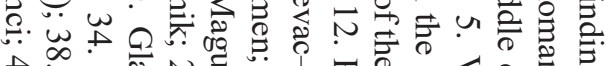

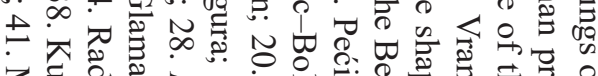

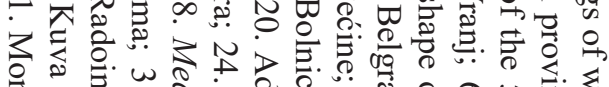

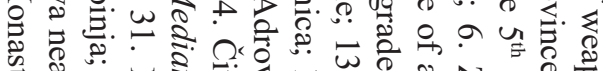

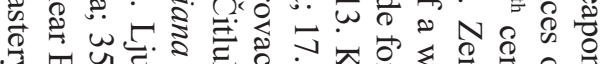
井品

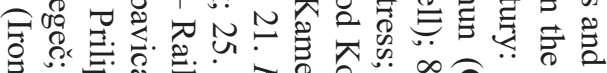
Q

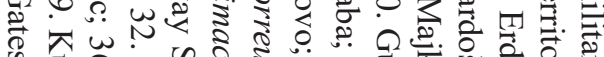

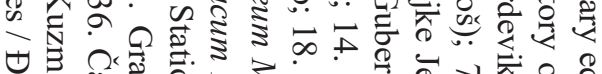

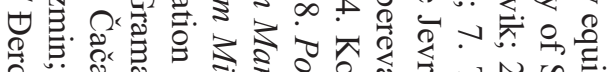
今ัम

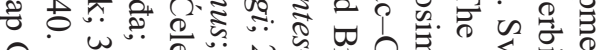

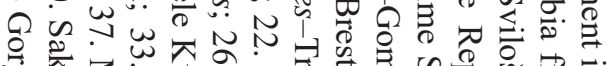

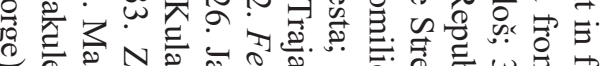

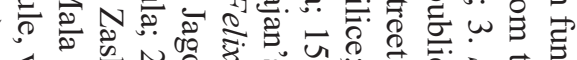

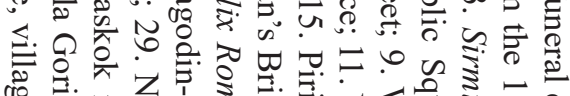
व

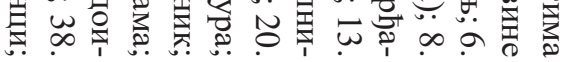
品 


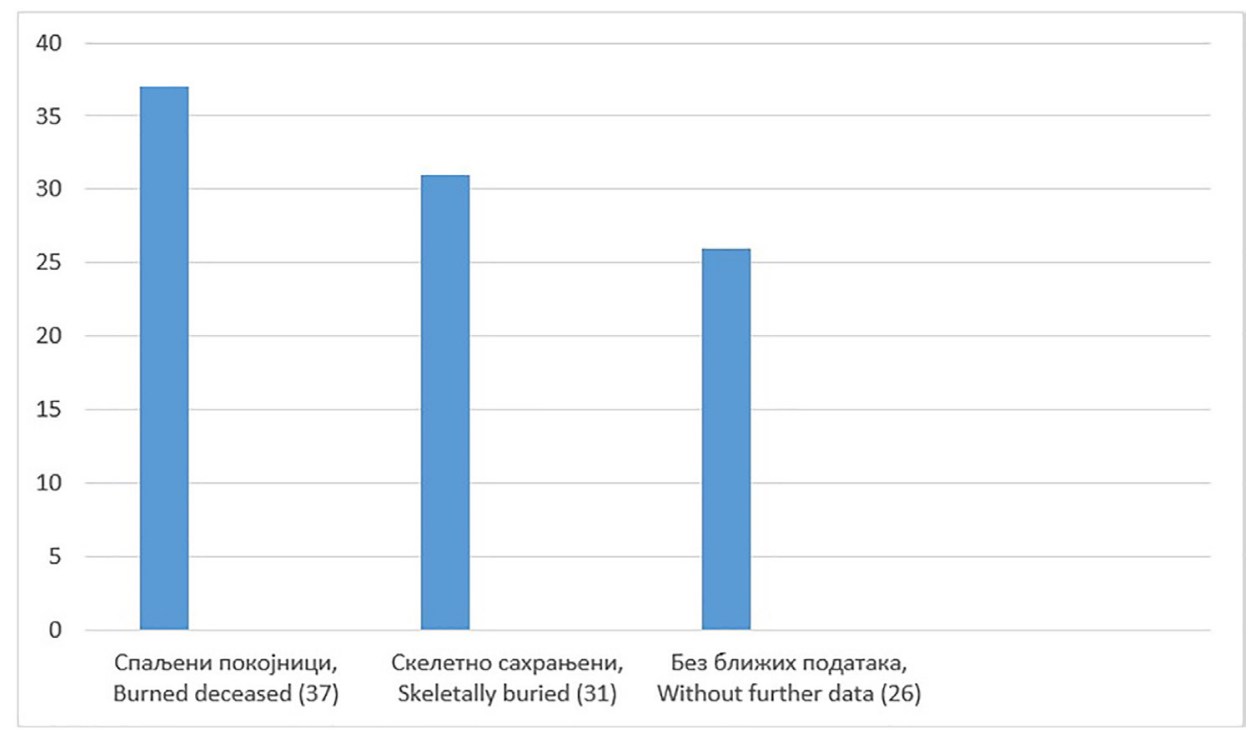

Graph 1. The ratio of the number of burned and skeletally buried individuals in whose graves findings of weapons and military equipment, from the $1^{\text {st }}$ up to the middle of the $5^{\text {th }}$ century in Roman provinces on the territory of Serbia

Графикон 1. Однос броја спаљених и скелетно сахрањених покојника у чијим гробовима су пронађени налази наоружања и војне опреме, од 1. до половине 5. века у римским провинцијама на територији Србије

compared to defensive weapons (16) (Graph 2) ${ }^{6}$. Of the offensive weapons, the following finds have been found in grave units so far: spears, arrows, knives, and daggers (they do not always have to be identified as finds of weapons), swords, axes, one ceramic slingshot projectile, as well as two reflex bow bone sheaths. The finds of defensive weapons include shield parts, armour, and helmets. Spears and arrows are the most common weapons in graves (Graph 3). In terms of grave goods in the form of a quiver, a ceramic slingshot projectile, and a pilum, only one example of each has been found (Graph 3).

When it comes to the finds of spears and arrows, it should be born in mind that they were often used by hunters. Thus, grave finds of spears and arrows may represent potential hunting equipment, as indicated by some foreign researchers (Márton 2002, 134). However, as it is difficult to establish the difference between hunting and military spears and arrows, it is almost impossible to

\footnotetext{
${ }^{6}$ It should be noted that the given ratios in Graphs 2 and 3 are made on the basis of the current state of research and available literature. Given that we still do not have the final number of such grave units, it is logical to expect that, during future archaeological research, there will certainly be more of them and that the stated ratio of offensive and defensive weapons will change accordingly.
} 


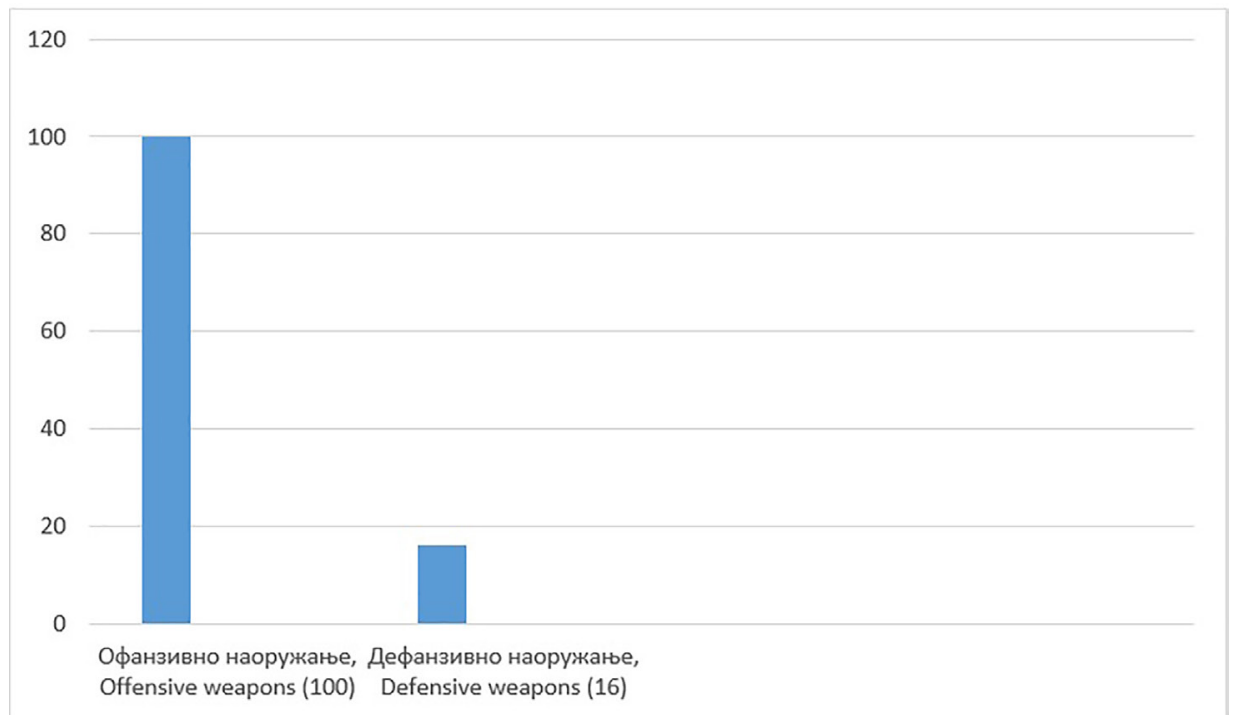

Graph 2. The ratio of offensive and defensive weapons found in grave contexts from the $1^{\text {st }}$ up to the middle of the $5^{\text {th }}$ century, in the area of Roman provinces on the territory of Serbia

Графикон 2. Однос офанзивног и дефанзивног наоружања пронађених у гробним контекстима од 1. до половине 5. века, на подручју римских провинција на територији Србије

determine the graves on this basis. The problem of "warrior" or "military" graves is complicated by the graves of women and children, in which there were also finds of weapons and military equipment. One such example comes from the territory of Serbia. It is an accidental find of a stone sarcophagus in Niška Banja in 1936, in which a gold earring, a grey-baked jug, and a spear were stored next to a child's skeleton. The grave is dated into the first half of the $4^{\text {th }}$ century (Јовановић 1994, 123) (List 71). Children's graves with weapons have been registered in areas of other provinces, but also in the area of Germania Magna, which did not belong to the territory of the Roman Empire. Children's graves from the early imperial period were found in this area with weapons of small dimensions, which indicates that they were made with a special purpose (Martin-Kilcher 2000, 74)7.

Graves that are being considered in this paper can be divided into several chronological frameworks, although their frequency is not the same in the period from the $1^{\text {st }}$ up to the middle of the $5^{\text {th }}$ century. They were most likely the result of

\footnotetext{
${ }^{7}$ Finds of weapons in the graves of children are also known from later periods. A leaf-shaped arrow with a barrel was found in the children's grave no. 4 at the Slav necropolis at the site of No. 99 Duga Ulica in Vinkovci (Sekelj Ivančan and Tkalčec 2006, 162, Pl. 8/2).
} 


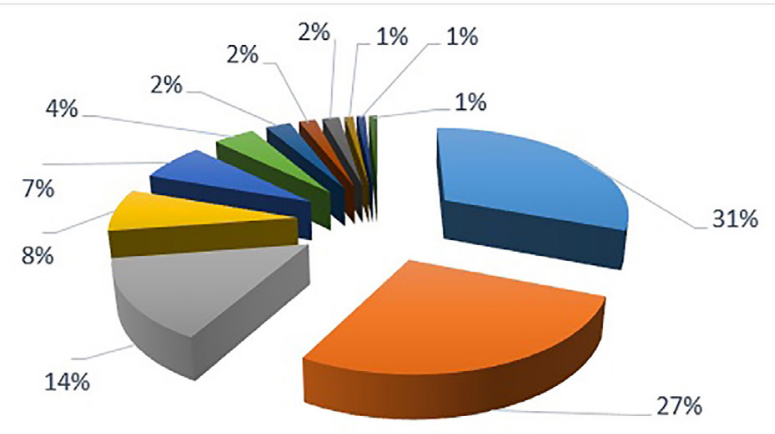

\begin{tabular}{|c|c|}
\hline 口 Копља, Spears (36) & 口 Стреле, Arrows (32) \\
\hline 口 Ножеви и бодежи, Knives and daggers (17) & Мачеви, Swords (9) \\
\hline 口 Делови штита, Shield parts (8) & 口 Оклопи, Armor (5) \\
\hline вШлемови, Helmets (3) & घекире, Axes (2) \\
\hline 口 Рефлексни лукови, Reflex bows (2) & घ Тоболац, Quiver (1) \\
\hline
\end{tabular}

Graph 3. The ratio of the number of weapons found in grave contexts from the $1^{\text {st }}$ up to the middle of the $5^{\text {th }}$ century in Roman provinces on the territory of Serbia

Графикон 3. Однос броја пронађеног наоружања у гробним контекстима од 1. до половине 5. века у римским провинцијама на територији Србије

several cultural, social, and ethnic influences under which they came into being. The lowest number of graves belongs to the $1^{\text {st }}$ century (List $\left.1-4\right)$. They can be seen as a trace of indigenous populations ${ }^{8}$, most likely members of Celtic tribes who retained their old burial customs - bending grave weapons. Among those were graves in the shape of a well (Sirmium, Singidunum, Viminacium) (List 2, 4, 24-26), which were also defined as Celtic. In this regard, we should not forget that the province of Upper Moesia, covering most of today's Serbia, is especially important, given that the active participation of the indigenous population was confirmed during the beginning of the $1^{\text {st }}$ century. Research in the field of epigraphy and onomastics shows that the main source of recruitment of the Upper Moesian legions IV Flavia and VII Claudia, during the $2^{\text {nd }}$ century however, were the members of native tribes of the province of Upper Moesia, as much as $72 \%$ (Ферјанчић 2008, 80). The question remains, however, did the autochthonous population, and to what extent, retain their traditional funerary customs, during Roman domination, including the placing of weapons as grave goods.

\footnotetext{
${ }^{8}$ Some foreign researchers see a number of grave finds from other provinces as a potential trace of the indigenous population in the service of the regular Roman army, i.e., auxiliary soldiers (Mráv 2013, Márton 2002, Bishop and Coulston 1993, 33).
} 
The next group includes high-rise graves (Mala Kopašnica-Sase) of cremated individuals (List 5-23), dated into the period between the $2^{\text {nd }}$ and the $3^{\text {rd }}$ century. They are often characterized by the presence of only one piece of weapon, most often a spear or an arrow, with several weapons registered in a small number of cases (List 10,16,17). Due to the fragmentation or poor preservation of anthropological remains in graves of this type, it is often impossible to determine the sex of the buried individual. Therefore, for a large number of high-rise graves in which weapons were found, it is only assumed that they belonged to male individuals. Also, the origin of this grave type has been the subject of scientific debate for a long time in archaeology, but still without a final solution (Cvjetićanin 2016).

The largest group of graves processed in this paper are those from the period of the $3^{\text {rd }}-4^{\text {th }}$ century, with the provision that some grave units can be dated into the middle of the $5^{\text {th }}$ century (List $30-50,53-56,60,62-67,71,76$ ). Unfortunately, for a large number of graves of this group, even basic data are unavailable because they were found by chance, so it is very difficult to provide more detailed analyses. However, some basic characteristics can be seen. Those were inhumed deceased individuals, with various forms of weapons and military equipment placed: swords, spears, arrows, parts of belts, shields, reflex bows, etc. For a certain number of deceased people in this group, it is possible to assume Germanic origin, which has been suggested in earlier literature.

At the site of Vranj near Hrtkovac, a grave of an inhumed man with traces of deformation on the skull was discovered, placed with parts of a sheath of a reflex bow and one biconical vessel (Dautova-Ruševljan 1998, 97) (List 34). According to the author V. Dautova-Ruševljan, this grave belonged to a warrior of Germanic origin from the end of the $4^{\text {th }}$ and the beginning of the $5^{\text {th }}$ century. This assumption is confirmed by the biconical vessel found in this tomb, decorated with geometric motifs, in polishing technique, which has its analogies in ceramic vessels found in the Czech Republic and Germany determined as a Germanic product (Dautova-Ruševljan 1998, 97).

Graves 27, 97, 123 at the necropolis Slog (Timacum Minus) near Ravna (List 35-37), from the end of the $4^{\text {th }}$ and the beginning of $5^{\text {th }}$ century, are presumed to belong to soldiers who served in auxiliary units of the Roman army, better known as Timacenses auxiliarii, recruited among the Eastern Goths or Alans (Petković and Miladinović-Radmilović 2014, 111-112). An inhumed individual in grave no. 7, not far from the ramparts of Pontes and Trajan's Bridge (List 49), may also have belonged to Germanic soldiers, since belt buckles of the Aquileian type were found near him, which were often used by Germanic soldiers or mercenaries in the service of federates (foederati) (Vujović 1998, 175). 
Graves 2/2006 and 3/2005 on the IV necropolis in Singidunum, from the end of the $4^{\text {th }}$ up to the middle of the $5^{\text {th }}$ century (List 55,56 ), undoubtedly belong to the group of Germanic warriors from the time of the Migration Period, formed within the Hun domination. They are characterized by weapons of oriental origin, such as swords of the "Asian" type with an iron protector, "nomadic" arrows. The Germanic origin of the warriors is also indicated by the deliberate breaking of weapons in that case, sword, spear, reflex bow sheath, while the fibula found in this grave is typical for Germanic populations in the Danube region (Ivanišević and Kazanski 2007).

Grave no. 50 of a cremated soldier from the end of the $3^{\text {rd }}$ - the beginning of the $4^{\text {th }}$ century found in Čačak seems to be interesting (List 30). A. Jovanović considered that the funerary feature of this grave, namely cremation and the presence of the recipient and weapons, resembled Germanic or Burgundian graves with similar characteristics (Јовановић 1994, 121).

Further in the paper, unique examples of grave weapons from the territory of Serbia will be listed, which provide new perspectives on the issue of interpretation of this funerary custom. Namely, in the Late Antique grave of an inhumed individual from the end of the $3^{\text {rd }}$ - the beginning of the $4^{\text {th }}$ century, not far from the ramparts of Felix Romuliana, among numerous finds of weapons, a bent spata was discovered (Živić 2007, IIb/5a) (List 51). As mentioned earlier, deliberate destruction and bending of weapons was typical of Celtic and Germanic funerary rites. It is difficult to say whether the influence of the Germanic funerary practice should be sought in the case of the bent spata from the Late Antique grave on Felix Romuliana, although such an assumption should not be rejected.

As a special grave unit from the territory of Serbia, a consecrated monument 2 stands out - a tumulus 2 from Magura, not far from Felix Romuliana, the place where emperor Galerius and his mother Romula ascended to godhood (Срејовић and Васић 1994, 15). Research has confirmed the remains of a monumental royal pyre (rogus) where the body was cremated, or more likely a wax figure (efigie) of Emperor Galerius, whose remains were placed in the nearby mausoleum 2 (Vujović 2017, 242). Among the numerous luxury items in Galerius tumulus, weapons were also found, which gives this imperial funerary context exceptional significance 9 .

The group of found weapons consists of: a spear, parts of a chainmail (lorica hamata), belt buckles and one fragment of a helmet paragnatide of the Intercisa or Berkasovo type (Vujović 2017, 244, Fig. 10-16) (List 32). Bearing in mind the significance of these finds, the question arises if the found military

${ }_{9}^{9}$ See papers: Srejović 1993, 47-48; Живић 2003, 72, cat. 262, 263, Vujović 2017. 
equipment perhaps belonged to emperor Galerius himself. No matter how tempting and logical it may seem, this question, unfortunately, still remains without a final answer. It must be borne in mind that tumulus 2 on Magura was looted and devastated during the Late Antique period. The chainmail armour found in Galerius' tumulus is one of the most reliable forms of this type of weapon, and was shown on coins from the period of the tetrarchy (Galerius, Constantine II and Licinius), which indicate that it could have been used for imperial public appearances (Vujović 2017, 247) ${ }^{10}$.

The problem of interpretation of this imperial funerary context is complicated by the fact that the exact place of Galerius' death in 311 has not been definitively determined. If the terrible death of that emperor really happened in Serdica (today's Sofia), then it is difficult to assume that the remains could have been quickly transported to Felix Romuliana, about $240 \mathrm{~km}$ away. It is more logical to assume that the emperor's wax figure was burned on tumulus 2 on Magura in a grandiose apotheosis, the last of its kind in Roman history. The wax figure which was publicly mourned and declared dead in Roman funerary customs (Cass. Dio, Hist. LXXV, 4; Herodian, 4.2.6-11) could have been dressed in Roman military equipment in that case, symbolizing Galerius as an emperor - warrior, who rose from his humble pastoral origin (Armentarius) to the imperial throne and became one of the most famous emperors of the Roman world (Vujović 2017, 248). The appearance of weapons in Galerius' imperial tumulus opens new questions in the field of considering grave finds of weapons, as a funerary practice that was not typical of the Romans.

The find of a shield that covered the body of the deceased over the head, torso and down to the knees, found in grave 2427 at the Viminacium necropolis Pećine is also worth mentioning. Only the metal parts of the band fittings of the shield which was the only object placed in that grave have survived. The grave is not chronologically determined, and the funerary custom itself, i.e., the way in which the deceased was buried, currently has no known analogy on the territory of the Roman Empire and is a unique example. It is interesting to mention that no shield umbo was found in the grave (Mrđić and Raičković 2013, 118, 121, Fig. 3) (List 51).

\section{Conclusion}

The analysis of previous finds of grave weapons on the territory of Serbia shows that this burial phenomenon has been recorded on numerous sites in Lower Pannonia, Dalmatia, and Upper Moesia. They appear almost equally in the graves

\footnotetext{
${ }^{10}$ In the area of Upper Moesia, a part of a chainmail (lorica hamata) was also found in grave 240 at the necropolis of Guberevac-Gomilice, on Kosmaj. It is a grave of a cremated individual, dated into the period of emperor Hadrian (Глумац 2014, 92, Fig. 147) (List 6).
} 
of cremated as well as inhumed deceased individuals. The analysed material in this paper shows that the presence of offensive weapons was significantly higher than that of defensive weapons.

The placement of weapons in graves of the deceased was practiced during the entire period of Roman domination in this area, from the $1^{\text {st }}$ up to the middle of the $5^{\text {th }}$ century. Their frequency was different over the centuries, and therefore, the grave units that are treated in this paper can be divided into several chronological frameworks. In the first place are the oldest chronologically determined graves from the $1^{\text {st }}$ century, which could be defined as a potential trace of autochthonous populations, which kept their old burial customs during the Roman period. In this respect, it should not be forgotten that the indigenous populations of the Upper Moesia were the main source of recruitment for the legions $I V$ Flavia and VII Claudia (as many as $72 \%$ ), which were permanently stationed in that province. However, it should be noted that such a relatively high percentage of recruitment refers to the $2^{\text {nd }}$ century, i.e., one century after the Roman conquest of the territory of the province of Upper Moesia.

A special group consists of high-rise graves (Mala Kopašnica-Sase) of cremated individuals from the period of the $2^{\text {nd }}-3^{\text {rd }}$ century. However, for now, it is not possible to decide on their ethnic origin with certainty.

Several grave units from the area of today's Serbia stand out for their unusualness and pose new questions about the funerary customs during the Roman period. First, these are the finds of weapons in a Late Antique grave, from the end of the $3^{\text {rd }}$ century - beginning of the $4^{\text {th }}$ century, found not far from the ramparts of Felix Romuliana, among which a deliberately bent spata stands out. This is especially important, since deliberate destruction and bending of weapons was practiced by Celts and Germans. Tumulus 2 on Magura, not far from Felix Romuliana, where the apotheosis of emperor Galerius took place, stands out as a separate unit. The finds of weapons discovered in this imperial funerary context pose new questions in the field of considering grave finds of weapons as a funerary practice that was not typical of the Romans. The wax figure of emperor Galerius, which was burned at the imperial stake in a grandiose apotheosis on Magura, the last of its kind in Roman history, may have been dressed in Roman military equipment. The tumuli on Magura and Šarkamen erected near the birthplace of emperors Galerius and Maximinus Daia should be viewed in the context of the imperial funerary practice (Јовановић 2006, 147, 203).

Several of the deceased from the graves analysed in this paper most likely belong to warriors of Germanic descent. Among them are graves in Vranj near Hrtkovci, Čačak, Pontes near Trajan's Bridge, at the necropolis Slog near Tima- 
cum Minus, as well as graves 3/2005 and 2/2006 at necropolis IV from the time of the Migration Period in Singidunum.

Numerous questions posed in this paper require obligatory linking between the research of prehistoric and Roman archaeology, joint treatment of many problems related to the period of the establishment of Roman rule - transitional period, but also analyses of grave units in territories inhabited by Germanic populations. We hope that future archaeological research will bring to light a significantly larger number of grave weapons from the Roman period, which will significantly complement our knowledge of this funerary phenomenon.

\section{List of grave units with findings of weapons and military equipment from the $1^{\text {st }}$ up to the middle of the $5^{\text {th }}$ century in Roman provinces on the territory of Serbia}

1. Zemun, Gardoš. Manner of burial / dating: cremated individual / $1^{\text {st }}$ century. Finds of weapons and military equipment: shield boss, shield grip, sword, knife, razor, spur, horse bit, spear (Hoffiller 1912, 67-68, sl. 27; Ercegović 1961, 125-137; Срејовић 1965, 58; Vujović 1998, 46, T XII/1, T XIV/6).

2. Sirmium (eastern necropolis) - 12 graves in the shape of wells. Manner of burial / dating: ? / $1^{\text {st }}$ century. Finds of weapons and military equipment: 6 spears, 3 swords, 5 arrows, 1 ах (Брукнер, Даутова-Рушевљан аnd Милошевић 1987, 13-24; Милошевић 2001, 159-163).

3. Sirmium (north-eastern necropolis). Manner of burial / dating: cremated individual / $1^{\text {st }}$ century. Finds of weapons and military equipment: spear (Брукнер, Даутова-Рушевљан and Милошевић 1987, 18, кат. бр. 28, Т. III/10).

4. Singidunum (The Republic Square) - grave in the shape of a well. Manner of burial / dating: ? / $1^{\text {st }}$ century. Finds of weapons and military equipment: part of a scale armour (lorica squamata)? (Валтровић 1885, 73; Vujović 2013, 32-34).

5. Mala Gorica 2 near Lederata. Manner of burial / dating: cremated individual / end of the $1^{\text {st }}$ century - beginning of the $2^{\text {nd }}$ century. Finds of weapons and military equipment: part of a laminated armour (lorica segmentata) (Цуњак and Јовановић 2014, 41, 48).

6. Guberevac - Gomilice. Manner of burial / dating: cremated individual / first half of $2^{\text {nd }}$ century. Finds of weapons and military equipment: part of a chain armour (lorica hamata) (Глумац 2014, 92, сл. 147).

7. Viminacium G1-1697. Manner of burial / dating: cremated individual / ? Finds of weapons and military equipment: spear (Mrđić and Raičković 2013, 120, fig. 14).

8. Viminacium G1-161. Manner of burial / dating: cremated individual $/ 2^{\text {nd }}$ century. Finds of weapons and military equipment: spear (Mrđić and Raičković 2013, 120, fig. 10).

9. Viminacium G1-222. Manner of burial / dating: cremated individual / $2^{\text {nd }}-$ first half of the $3^{\text {rd }}$ century. Finds of weapons and military equipment: arrow (Зотовић and Јордовић 1990. 102-103, T. CLXXIV/1-3; Mrđić and Raičković 2013, 120, fig. 11). 
10. Viminacium G1-579. Manner of burial / dating: cremated individual / ? Finds of weapons and military equipment: arrow, fragmented knife (Mrđić and Raičković 2013, 119, fig. 8). 11. Viminacium G1-20. Manner of burial / dating: cremated individual / ? Finds of weapons and military equipment: spear (Mrđić and Raičković 2013, 119, fig. 5).

12. Viminacium G1-461. Manner of burial / dating: cremated individual / $2^{\text {nd }}$ century. Finds of weapons and military equipment: spear (Mrđić and Raičković 2013, 120, fig. 12).

13. Viminacium G1-531. Manner of burial / dating: cremated individual / ? Finds of weapons and military equipment: arrow (Mrđić and Raičković 2013, 120, fig. 13).

14. Viminacium G1-91. Manner of burial / dating: cremated individual / end of the $2^{\text {nd }}$ century. Finds of weapons and military equipment: arrow (Golubović 2004, 71, 203, T. LXIII; Mrđić and Raičković 2013, 119, fig. 6).

15. Viminacium G1-329. Manner of burial / dating: cremated individual / ? Finds of weapons and military equipment: arrow (Mrđić and Raičković 2013, 119, fig. 7).

16. Viminacium G1-58. Manner of burial / dating: cremated individual / $2^{\text {nd }}$ century. Finds of weapons and military equipment: part of a scabbard, part of a sword, dagger, part of a belt (Зотовић and Јордовић 1990, 84, T. LXXXVI/ 1-7; Mrđić and Raičković 2013, 119, fig. 9). 17. Ljubavica - grave no. 12. Manner of burial / dating: cremated individual / first half of the $3^{\text {rd }}$ century. Finds of weapons and military equipment: arrow, knife (Пејић 1993, 25-26, T. 5).

18. Viminacium G1-32. Manner of burial / dating: cremated individual / middle of the $2^{\text {nd }}$ century. Finds of weapons and military equipment: part of a belt (Golubović 2004, 71, 159-160, T. XXX, XXXI).

19. Viminacium G1-99. Manner of burial / dating: cremated individual / middle of the $2^{\text {nd }}$ century. Finds of weapons and military equipment: part of a belt (Golubović 2004, 70, 210-211, T. LXXI, LXXII).

20. Viminacium G1-41. Manner of burial / dating: cremated individual / end of the $2^{\text {nd }}$ century. Finds of weapons and military equipment: part of a belt (Golubović 2004, 70, 167-168, T. XXXVIII, T XXXIX, T. XL).

21. Viminacium G1-74. Manner of burial / dating: cremated individual / end of the $2^{\text {nd }}$ century. Finds of weapons and military equipment: part of a belt (Golubović 2004, 70, 191, T. CLII).

22. Viminacium G1-66. Manner of burial / dating: cremated individual / middle of the $2^{\text {nd }}$ century. Finds of weapons and military equipment: part of a belt (Golubović 2004, 70, 183-184, T. LV).

23. Viminacium G1-1570, G1-1622, G1-291, G1-716, G1-695, G1-622, G1-64, G1-490

( 8 graves). Manner of burial / dating: cremated individuals / middle of the $2^{\text {nd }}-$ middle of the $3^{\text {rd }}$ century. Finds of weapons and military equipment: finds of military belt sets VTERE FELIX (Redžić 2008, 155-162).

24. Viminacium G1-70 - grave in the shape of a well. Manner of burial / dating: cremated individual / middle of the $2^{\text {nd }}$ century. Finds of weapons and military equipment: spear (Golubović 2008, 20-21, 156, T.2). 
25. Viminacium G1-263 - grave in the shape of a well. Manner of burial / dating: cremated individual / first decade of the $2^{\text {nd }}$ century - middle of the $3^{\text {rd }}$ century. Finds of weapons and military equipment: 2 trilobate arrows (Golubović 2008, 24-28, 159-160, T. 5, 6).

26. Viminacium G1-295 grave in the shape of a well. Manner of burial / dating: cremated individual / beginning of the $2^{\text {nd }}$ century - last decade of the $3^{\text {rd }}$ century. Finds of weapons and military equipment: arrow nock (Golubović 2008, 32-34, 165-166, T. 11, 12; Вујовић 2019-2020, 233-242).

27. Viminacium G 18 (pit 3) - part of a sacrificial surface. Manner of burial / dating: ? / from the beginning up to the end of $2^{\text {nd }}$ century. Finds of weapons and military equipment: part of a belt and horse harness (Golubović 2008, 60-65, 190, 192, T. 36, 38).

28. Viminacium pit 3, part of sacrificial surface 3. Manner of burial / dating: cremated individual / beginning of the $2^{\text {nd }}-$ beginning of the $3^{\text {rd }}$ century. Finds of weapons and military equipment: spear, shield boss, ceramic slingshot projectile (Golubović 2008, 71-77, T. 49/26, 54/25, 57/35).

29. Vranj near Hrtkovci. Manner of burial / dating: cremated individuals / middle or second half of the $2^{\text {nd }}$ century. Finds of weapons and military equipment: shield boss (Dautova-Ruševljan 1986-1987, 103, T I, IV; Dautova-Ruševljan 1991, 43; Vujović 1998, 46, T XIII/2).

30. Cačak, gate of the Church of the Assumption of the Blessed Virgin - grave no. 50. Manner of burial / dating: cremated individual / second half of the $3^{\text {rd }}$ - second half of the $4^{\text {th }}$ century. Finds of weapons and military equipment: spear, knife, ax (Дмитровић and Радичевић 2009, 14, кат. бр. 81, 82, 83, 84, 85, 86, 87).

31. Felix Romuliana. Manner of burial / dating: cremated individual (very few remains) / end of the $3^{\text {rd }}$ - beginning of the $4^{\text {th }}$ century. Finds of weapons and military equipment: bent sword (spatha), dagger, spear, shield boss, horse bit, ring for hanging a sword on a belt (Živić 2007, 277-307; Petković 2007, 251-257; Dimitrijević and Medović 2007, 315-323; Поп-Лазић 2013, 70, сл. 21).

32. Magura - consecrative monument 2. Manner of burial / dating: cremated individual / beginning of the $4^{\text {th }}$ century. Finds of weapons and military equipment: part of a chain armour (lorica hamata), dagger, spear, part of a helmet, parts of a belt (Срејовић and Васић 1994; Vasić 1997; Живић 2003, 262-265; Поповић 2010, 141-158; Vujović 2017, 239-250).

33. Šarkamen - (burial mound) - grave no. 6. Manner of burial / dating: cremated individual / beginning of the $4^{\text {th }}$ century. Finds of weapons and military equipment: knife, spear (Tomović et al. 2005, 36-49, cat. no. 86-92).

34. Vranj near Hrtkovci. Manner of burial / dating: skeletally buried individual / end of the $4^{\text {th }}$ - beginning of the $5^{\text {th }}$ century. Finds of weapons and military equipment: bone parts of a reflex bow (Dautova-Ruševljan 1998, 97-101).

35. Timacum Minus - grave no. 27. Manner of burial / dating: skeletally buried individual / end of the $4^{\text {th }}$ - beginning of $5^{\text {th }}$ century. Finds of weapons and military equipment: arrow, parts of a belt (Petković et al. 2005, 29, 100, Pl. IV/G. 27; Petković and Miladinović-Radmilović 2014, 87-130; Миладиновић-Радмиловић, Ђукић and Вуловић 2016, 53-67). 
36. Timacum Minus - grave no. 97. Manner of burial / dating: skeletally buried individual / end of the $4^{\text {th }}$ - beginning of $5^{\text {th }}$ century. Finds of weapons and military equipment: spear, arrow (Petković et al. 2005, 41, 100, Pl. X/G. 97; Petković and Miladinović-Radmilović 2014, 87-130; Миладиновић-Радмиловић, Ђукић and Вуловић 2016, 53-67).

37. Timacum Minus - grave no. 123. Manner of burial / dating: skeletally buried individual / end of the $4^{\text {th }}$ - beginning of the $5^{\text {th }}$ century. Finds of weapons and military equipment: arrow (Petković et al. 2005, 43, 100, Pl. X/G. 123; Petković and Miladinović-Radmilović 2014, 87-130; Миладиновић-Радмиловић, Ђукић and Вуловић 2016, 53-67).

38. Horreum Margi. Manner of burial / dating: skeletally buried individual / ? Finds of weapons and military equipment: 2 spears (Piletić 1969, 20, 22, sl. 28; Пековић 2007, 83, сл. 61; Јовановић 1994, 123).

39. Gomolava - grave no. 4. Manner of burial / dating: Skeletally buried individual / $3^{\text {rd }}$ $4^{\text {th }}$ century. Finds of weapons and military equipment: part of a belt (Dautova-Ruševljan and Brukner 1992, 168, T. 2).

40. Gomolava - grave no. 14. Manner of burial / dating: skeletally buried individual /

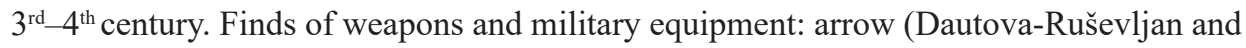
Brukner 1992, 169, T. 5).

41. Gomolava - grave no. 33. Manner of burial / dating: skeletally buried individual / $3^{\text {rd }}-4^{\text {th }}$ century. Finds of weapons and military equipment: spear (Dautova-Ruševljan and Brukner 1992, 171, T. 10).

42. Sviloš - grave no. 41. Manner of burial / dating: skeletally buried individual/ middle of the $4^{\text {th }}$ century. Finds of weapons and military equipment: part of a belt, knife (DautovaRuševljan 2003, 20, 117, T XVIII).

43. Beška - grave no. 5. Manner of burial / dating: skeletally buried individual / $4^{\text {th }}$ century. Finds of weapons and military equipment: part of a belt (Manojlović-Marijanski 1987, 37, T. 10).

44. Beška - grave no. 15. Manner of burial / dating: skeletally buried individual / $4^{\text {th }}$ century. Finds of weapons and military equipment: part of a belt (Manojlović-Marijanski 1987, 41, T. 16).

45. Beška - grave no. 19. Manner of burial / dating: skeletally buried individual / $4^{\text {th }}$ century. Finds of weapons and military equipment: part of a belt (Manojlović-Marijanski 1987, 43, T. 18).

46. Beška - grave no. 47. Manner of burial / dating: skeletally buried individual / $4^{\text {th }}$ century. Finds of weapons and military equipment: part of a belt (Manojlović-Marijanski 1987, 51, T. 31).

47. Čitluk - grave no. 126. Manner of burial / dating: skeletally buried individual / $4^{\text {th }}$ century. Finds of weapons and military equipment: knife, part of a belt (Рашковић 2014, 208-209, Т 5/1,2; Шпехар 2007, 282).

48. Zaskok near Uroševac. Manner of burial / dating: skeletally buried individual / end of the $3^{\text {rd }}$ - beginning of the $4^{\text {th }}$ century. Finds of weapons and military equipment: part of a belt (Поповић 1994, 53, кат. бр. 247-249). 
49. Pontes - Trajan's Bridge - grave no. 7. Manner of burial / dating: skeletally buried individual / end of the $4^{\text {th }}$ - beginning of the $5^{\text {th }}$ century. Finds of weapons and military equipment: part of a belt set (Чернач-Ратковић 1994, 159-163; Vujović 1998, 174-175, T LII/4; Поп-Лазић 2013, 70, сл. 22).

50. Jagodin mala - grave no. 19. Manner of burial / dating: skeletally buried individual/ second half of the $4^{\text {th }}$ century. Finds of weapons and military equipment: parts of a belt set (Дрча et al. 2014, 23-25, сл. 13, кат. бр. 74, 148, 186).

51. Viminacium G-2427. Manner of burial / dating: skeletally buried individual / ? Finds of weapons and military equipment: shield fittings (Mrđić and Raičković 2013, 118, fig. 3).

52. Viminacium G-443. Manner of burial / dating: skeletally buried individual / ? Finds of weapons and military equipment: spear (Korać and Golubović 2009, 365; Mrđić and Raičković 2013, 119, fig. 8).

53. Viminacium G-291. Manner of burial / dating: skeletally buried individual / middle of the $3^{\text {rd }}$ century. Finds of weapons and military equipment: knife (Golubović 2004, 71, 264, T. CXX).

54. Viminacium G-152. Manner of burial / dating: skeletally buried individual / middle of the $4^{\text {th }}$ century. Finds of weapons and military equipment: arrow (Golubović, Mrđić and Scott Speal 2007, 55-63).

55. Singidunum - grave no. 3/2005. Manner of burial / dating: skeletally buried individual / end of the $4^{\text {th }}$ - beginning of the $5^{\text {th }}$ century. Finds of weapons and military equipment: shield boss (Ivanišević and Kazanski 2007, 115, fig. 3).

56. Singidunum - grave no. 2/2006. Manner of burial / dating: Skeletally buried individual / 430s-440s ( $5^{\text {th }}$ century). Finds of weapons and military equipment: Part of a belt set, knife, fragmented sword, shield boss, shield grip, fragmented spear, fragmented bone parts of a reflex bow, part of a quiver, 10 arrows (Ivanišević and Kazanski 2007, 116, fig. 4-10). 57. Požarevac - Bolnica. Manner of burial / dating: ? / $2^{\text {nd }}-3^{\text {rd }}$ century. Finds of weapons and military equipment: sword, 2 spears, pilum, bent knife (Piletić 1971, 8-10. цртеж бр. 14-20, 24; Vujović 1998, 58, T XVIII/ 1).

58. Kamenovo - Međe gave no. 1. Manner of burial / dating: ? / ? Finds of weapons and military equipment: bent arrow (Piletić 1971, 9-10, цртеж бр. 21-30).

59. Kamenovo - Međe grave no. 2. Manner of burial / dating: ? / ? Finds of weapons and military equipment: 2 spears, 3 knifes (Piletić 1971, 9-10, цртеж бр. 21-30).

60. Vinik near Niš. Manner of burial / dating: ? / $3^{\text {rd }}-4^{\text {th }}$ century ? Finds of weapons and military equipment: helmet (Nenadović 1961, 167-168; Vujović 1998, 18, T II/4).

61. Singidunum (No. 36 of Majke Jevrosime Street). Manner of burial / dating: Skeletally buried individual / ? Finds of weapons and military equipment: part of a belt, horse bit (Pop-Lazić 2000, T. XXX; Pop-Lazić 2002, 28, sl. 22/10, 13, 23/13, 18).

62. Sirmium - grave no. 36. Manner of burial / dating: ? / first half of the $4^{\text {th }}$ century. Finds of weapons and military equipment: spear, part of a belt (Јовановић 1994, 123).

63. Sirmium - grave no. 38. Manner of burial / dating: ? / first half of the $4^{\text {th }}$ century. Finds of weapons and military equipment: spear, part of a belt (Јовановић 1994, 123). 
64. Prilipac. Manner of burial / dating: skeletally buried individual/ second half of the $4^{\text {th }}$ century? Finds of weapons and military equipment: spear (Јовановић 1994, 122).

65. Mediana, Railway Station Ćele Kula. Manner of burial / dating: skeletally buried individual / first half of the $4^{\text {th }}$ centuy. Finds of weapons and military equipment: spear (Jacanović 1981, 97-98; Јовановић 1994, 122).

66. Ruma "Borkovac". Manner of burial / dating: ? / $3^{\text {rd }}-4^{\text {th }}$ century. Finds of weapons and military equipment: "findings of weapons" only mentioned in the literature, without precise data (Јовановић 1994, 123).

67. Radoinja "Bjelin" - grave 3/54. Manner of burial / dating: skeletally buried individual / end of the $3^{\text {rd }}$-beginning of the $4^{\text {th }}$ century. Finds of weapons and military equipment: arrow (Јовановић 1994, 122).

68. Adrovac near Rača. Manner of burial / dating: ? / ? Finds of weapons and military equipment: arrow (Јовановић 1994, 122).

69. Erdevik. Manner of burial / dating: ? / ? Finds of weapons and military equipment: spear (Јовановић 1994, 123).

70. Gramađa. Manner of burial / dating: skeletally buried individual / ? Finds of weapons and military equipment: spear (Јовановић 1994, 122).

71. Niška Banja. Manner of burial / dating: skeletally buried individual / first half of the $4^{\text {th }}$ century. Finds of weapons and military equipment: spear (Јовановић 1994, 123).

72. Glama near Bela Palanka (Remesiana). Manner of burial / dating: ? / ? Finds of weapons and military equipment: spear (Јовановић 1994, 123).

73. "Kuva" near Begeč. Manner of burial / dating: ? / ? Finds of weapons and military equipment: sword, shield boss (Dautova-Ruševljan 1972-1973, 144, T IV/1).

74. Kuzmin. Manner of burial / dating: skeletally buried individual / ? Finds of weapons and military equipment: "findings of weapons" only mentioned in the literature, without precise data (Славнић 1952, 60).

75. Sakule, village of Deč, Municipality of Pećinci. Manner of burial / dating: ? / ? Finds of weapons and military equipment: parts of an armour (without precise data) (Popović 1967, 174).

76. Monastery (Đerdap Gorge / Iron Gates). Manner of burial / dating: skeletally buried individual $/ 4^{\text {th }}$ century. Finds of weapons and military equipment: helmet application with a Chi-Ro motive (Vujović 2012, 29-43, fig. 1/1, Pl. I/13).

\section{ANCIENT SOURCES}

Cassius Dio - Roman History, Volume IX, Books 71-80. Loeb Classical Library 177. E. Cary (tr.), Cambridge-London, 2001.

Herodian - Herodian of Antioch's History of the Roman Empire. E. C. Echols (tr.), Berkeley and Los Angeles, 1961.

Tacitus Cornelius - Germania, University of California Libraries, 1890.

Vegetius - Epitome Rei Militaris. Reeve M. D. (tr.), Oxford University Press, 2004. 


\section{REFERENCES}

Aarts, J. and Heeren, S. 2017. Buried Batavians: Mortuary rituals of a rural frontier community, in Death as a Process: Studies in Funerary Archaeology Vol. 12. eds. J, Pearce and J. Weekes. 123-154. Oxford \& Philadelphia: Oxbow Books.

Бабић, С. 2004. Поглаварство и полис. Београд: Српска академија наука и уметности, Балканолошки институт.

Benac, A. and Čović, B. 1957. Glasinac II - Željezno doba. Sarajevo: Zemaljski muzej. Bishop, M. C. and Coulston, J. C. N. 1993. Roman Military Equipment from Punic Wars to the fall of Rome. London: Oxbow Books.

Брукнер, О. Даутова-Рушевљан, В. and Милошевић, П. 1987. Почеци романизаuије у југоисточном делу провиничје Паноније. Нови Сад: Матица српска.

Bülow von, G. 2013. Romuliana-Gamzigrad in der provinz Dacia Ripensis - ein neu entdecktes waffengrab, in Proceedings of the XVIIth Roman Military Equipment Conference Weapons and Military Equipment in a Funerary Context, eds. M. Sanader, A. Rendić-Miočević, D. Tončinić and I. Radman-Livaja. 151-155. Zagreb: Filozofski fakultet Sveučilišta u Zagrebu, Odsjek za arheologiju; Arheološki muzej u Zagrebu.

Cvjetićanin, T. 2016. Grobovi tipa Mala Kopašnica - Sase: narativ o kontinuitetu. Етноантрополошки проблеми, н. с. год. 11 св. 3: 711-730.

Czarnecka, K. 2013. Warriors in this World and the Afterlife Przeworsk Culture Graves Containing Weapons, in Proceedings of the XVIIth Roman Military Equipment Conference Weapons and Military Equipment in a Funerary Context, eds. M. Sanader, A. Rendić-Miočević, D. Tončinić and I. Radman-Livaja. 163-175. Zagreb: Filozofski fakultet Sveučilišta u Zagrebu, Odsjek za arheologiju; Arheološki muzej u Zagrebu.

Цуњак, М. and Јовановић, А. 2014. Ледерата у светлу резултата досадашњих истраживања. Велико Градиште-Рам: Народна библиотека „Вук Караџић”.

Чернач-Ратковић, С. 1994. Оков појасне копче Аквилеја типа из кастела Понтес. Гласник Српског археолошког друштва 11: 159-163.

Dautova-Ruševljan, V. 1972-1973. Zaštitno iskopavanje antičkog lokaliteta „Kuva” kod Begeča. Rad vojvođanskih muzeja 21-22: 141-152.

Dautova-Ruševljan, V. 1986-1987. Grobni nalazi sa Vranja i Gomolave. Rad vojvođanskih muzeja 30: 103-112.

Dautova-Ruševljan, V. 1991. Sondažno-zaštitna iskopavanja na lokalitetu Vranj kod Hrtkovaca u Sremu (1980-1989). Rad vojvođanskih muzeja 33: 41-62.

Dautova-Ruševljan, V. and Brukner, O. 1992. Gomolava: rimski period. Novi Sad: Vojvođanski muzej.

Dautova-Ruševljan, V. 1998. Kasnoantički grob sa lokaliteta Vranj u Hrtkovcima. Rad vojvođanskih muzeja 40: 97-101.

Dautova-Ruševljan, V. 2003. Kasnoantička nekropola kod Sviloša u Sremu. Novi Sad: Matica srpska, Muzej Vojvodine.

Dimitrijević, V. and Medović, A. 2007. Animal and Plant Remains in a Tomb in test-pit 1/05, outside the Fortified Imperial Palace Felix Romuliana. Старинар LVII: 315-323. 
Dizdar, M. Šoštarić, J. and Jelinčić, K. 2003. Ranorimski grob iz Iloka kao prilog poznavanju romanizacije zapadnog Srijema. Prilozi Instituta za arheologiju u Zagrebu 20: 57-77.

Dizdar, M. and Radman-Livaja, I. 2004. Nalaz naoružanja iz Vrtne ulice u Vinkovcima kao prilog poznavanju rane romanizacije istočne Slavonije. Prilozi Instituta za arheologiju u Zagrebu 21: 37-53.

Dizdar, M. and Potrebica, H. 2014. Late La Tène Warrior Grave from Mali Bilač (Požega Valley, Croatia). Opera Instituti Archaeologici Sloveniae 30: 355-376.

Dizdar, M. and Radman-Livaja, I. 2015. Continuity of the Late La Tène warrior elite in the Early Roman Period in south-eastern Pannonia, in Waffen-Gewalt-Krieg Hrsg. S. Wefers, M. Karwowski, J. Fries-Knoblach, P. Trebsche, P. C. Ramsl. Beitrage zur Internationalen Tagung der AG Eisenzeit und des Instytut Archeologii Uniwersytetu Rzeszowskiego-Rzeszow 19.-22. September 2012, Langenweißbach, BUFM, 79: 209-227.

Дмитровић, К. and Радичевић, Д. 2009. Касноантичка некропола у Чачку. Чачак: Народни музеј Чачак.

Дрча, C. et al. 2014. Јагодин мала касноантичка некропола. Ниш: Народни музеј Ниш. Ercegović, S. 1961. Keltski konjanički grob s Gardoša u Zemunu. Vjesnik Arheološkog muzeja u Zagrebu 2: 125-137.

Ферјанчић, С. 2008. Регрутација горњомезијских легија IV Flavia и VII Claudia. Зборник Народног музеја у Чачку XXXVIII: 63-82.

Филиповић, В. 2009. Мамузе из млађег гвозденог доба у Србији. Гласник Српског археолошког друштва 25: 163-188.

Глумац, М. 2014. Римска некропола Губеревац-Гомилице на Космају: социјална структура становништва од I до III века н. е. Докторска дисертација. Универзитет у Београду.

Golubović, S. 2004. Sahranjivanje u Viminacijumu od I do IV veka. Doktorska disertacija. Univerzitet u Beogradu.

Golubović, S. Mrđić, N. and Scott Speal C. 2007. Killed by the arrow: grave No. 152 from Viminacium, in Waffen in Aktion, Akten der 16. Internationalen Roman Military Equipment Conference, eds. A. W. Busch and Hans-Joachim S. 55-63. Mainz: Verlag Philipp von Zabern.

Golubović, S. 2008. Grobovi u obliku bunara sa nekropola Viminacijuma. Beograd: Arheološki institut.

Grane, T. 2008. South Scandinavian foederati and auxiliarii? Journal of Roman Military Equipment Studies 16: 69-80.

Гроздић, Б. Кузмановић, С. and Николић, Б. 2011. Војна етика у систему наука и њен однос према наукама о одбрани, у Војно дело, општевојни научно-теоријски часопис (лето 2011), ур. Д. Марковић. 237-250. Београд: Министарство одбране Републике Србије.

Hoffiller, V. 1912. Oprema rimskoga vojnika u prvo doba carstva II. Vjesnik Arheološkog muzeja u Zagrebu. Vol. 12: 16-123. 
Ivanišević, V. and Kazanski, M. 2007. Nouvelle Necropole des Grandes Migrations de Singidunum. Старинар LVII: 113-135.

Istenič, J. 2013. Early Roman Graves with Weapons in Slovenia: An Overview, in Proceedings of the XVIIth Roman Military Equipment Conference Weapons and Military Equipment in a Funerary Context, eds. M. Sanader, A. Rendić-Miočević, D. Tončinić and I. Radman-Livaja. 23-35. Zagreb: Filozofski fakultet Sveučilišta u Zagrebu, Odsjek za arheologiju; Arheološki muzej u Zagrebu.

Jacanović, D. 1981. Medijana, žel. stanica Ćele Kula - kasnoantička nekropola. Arheološki pregled 22: 97-98.

Jensen, P. X. 2013. Imitation and Transformation - Roman Militaria in South Scandinavian Grave Finds, in Proceedings of the XVIIth Roman Military Equipment Conference Weapons and Military Equipment in a Funerary Context, eds. M. Sanader, A. RendićMiočević, D. Tončinić and I. Radman-Livaja. 177-183. Zagreb: Filozofski fakultet Sveučilišta u Zagrebu, Odsjek za arheologiju; Arheološki muzej u Zagrebu.

Јовановић, А. 1994. О проблему касноантичких гробова с оружјем на тлу Србије. Зборник Народног музеја 15-1: 119-132.

Јовановић, А. 2006. Тло Србије - завичај римских изарева. Београд: Принцип-Бонарт прес.

Kagan, D. and Viggiano, G. F. 2013. Men of Bronze: Hoplite Warfare in Ancient Greece. New Jersey and Oxford: Princeton University Press.

Карије, Ж. М. 2006. Војник, у Ликови Старог Рима, ур. А. Ђардина (превели: Мила Самарџић, Јасна Видић и Јелена Косовац). 119-163. Београд: Клио.

Korać, M. and Golubović, S. 2009. Viminacium 2. Više Grobalja. 281-530 (kremacija), 268-550 (inhumacija). Beograd: Arheološki institut.

Lloyd, M. 2014. The Archaeology of Greek Warriors and Warfare from the Eleventh to Early Seventh Century B. C. E. University of Oxford: Merton College.

Manojlović-Marijanski, M. 1987. Rimska nekropola kod Beške u Sremu. Novi Sad: Vojvođanski muzej.

Martin-Kilcher, S. 2000. Mors immatura in the Roman world-a mirror of society and tradition, in Burial, Society and Context in the Roman World, eds. J. Pearce, M. Millett and M. Struck. 63-77. Oxford: Oxbow Books.

Márton, A. 2002. Roman burial with a weapon from the Besci road cemetery (Aquincum-Budapest), in Communicationes Archaeologicae Hungariae, ed. F. István. 117-152. Budapest: Nemzeti Museum.

Mattingly, J. 2011. Imperialism, Power, and Identity. Experiencing the Roman Empire. Princeton and Oxford: Princeton University Press.

MacMullen, R. 1960. Inscriptions on Armor and the Supply of Arms in the Roman Empire. American Journal of Archaeology 64.1: 23-40.

Миладиновић-Радмиловић, Н. Ђукић, К. and Вуловић, Д. 2016. Трагови насилних повреда у пределу главе и врата на примеру скелетних остатака из историјских периода у Србији. Весник, часопис за историју, музеологију и уметност 43: 53-67. 
Милинковић, М. 1998. Германска племена на Балкану: археолошки налази из времена сеобе народа, Докторска дисертација. Универзитет у Београду.

Милошевић, П. 2001. Археологија и историја Сирмијума. Нови Сад: Матица српска. Morris, I. 1992. Death - Ritual and Social Structure in Classical Antiquity. Cambridge: University Press.

Mráv, Z. 2013. Graves of Auxiliary Soldiers and Veterans from the First Century AD in the Northern Part of Pannonia, in Proceedings of the XVIIth Roman Military Equipment Conference, Weapons and Military Equipment in a Funerary Context, eds. M. Sanader, A. Rendić-Miočević, D. Tončinić and I. Radman-Livaja. 57-116. Zagreb: Filozofski fakultet Sveučilišta u Zagrebu, Odsjek za arheologiju; Arheološki muzej u Zagrebu.

Mrđić, N. and Raičković, A. 2013. Soldier Burials with Weapons at Viminacium Cemetery, in Proceedings of the XVIIth Roman Military Equipment Conference Weapons and Military Equipment in a Funerary Context, eds. M. Sanader, A. Rendić-Miočević, D. Tončinić and I. Radman-Livaja. 117-132. Zagreb: Filozofski fakultet Sveučilišta u Zagrebu, Odsjek za arheologiju; Arheološki muzej u Zagrebu.

Nenadović, A. 1961. Raniji rimski nalasci u Nišu i njegovoj bližoj okolini. Limes u Jugoslaviji I: $165-170$.

Nicolay, J. 2007. Armed Batavians: Use and significance of weaponry and horse gear from non military contexts in the Rhine delta (50 BC to AD 450). Amsterdam: University Press.

Novak, M. 2013. Tavern Brawls, Banditry and Battles - Weapon Injuries in Roman Iader, in Proceedings of the XVIIth Roman Military Equipment Conference Weapons and Military Equipment in a Funerary Context, eds. M. Sanader, A. Rendić-Miočević, D. Tončinić and I. Radman-Livaja. 347-355. Zagreb: Filozofski fakultet Sveučilišta u Zagrebu, Odsjek za arheologiju; Arheološki muzej u Zagrebu.

Olson, B. R. 2013. Roman Infantry Helmets and Commemoration Among Soldiers. Vulcan 1: 3-19.

Palavestra, A. 1997. Glasinačka kultura, u Arheološki leksikon, ur. D Srejović. 316-319. Beograd: Savremena administracija.

Пејић, П. 1993. Римске некрополе и насеље код Мале Лукање на Старој планини. Магистарски рад. Универзитет у Београду.

Пековић, М. 2007. Војни музеј: Пет деценија археолошких истраживања 19542004. Београд: Српско археолошко друштво, Војни музеј - Београд.

Pearce, J. 2017. Introduction: Death as a process in Roman funerary archaeology, in Death as a Proccess: Studies in Funerary Archaeology Vol. 12. eds. J, Pearce and J. Weekes. 1-26. Oxford \& Philadelphia: Oxbow Books.

Pearson, P. 2003. The Archaeology of Death and Burial. Phoenix Mill: Sulton Publishing. Pernet, L. 2010. Armement et auxiliaires gaulois II et $I^{e r}$ siècles avant notre ère. Université de Lausanne: Éditions Monique Mergoil Montagnac.

Petković, S. et al. 2005. Roman and Medieval Necropolis in Ravna near Knjaževac. Belgrade: the Institute of Archaeology. 
Petković, S. 2007. Late Necropolis of Romuliana, Area South of the Fortified Palace (Research 2005-2006). Старинар LVII: 251-275.

Петковић, С. 2010. Ромулијана у време после царске палате, у Felix Romuliana Гамзиград, ур. И. Поповић. 167-199. Београд: Археолошки институт.

Petković, S. and Miladinović-Radmilović, N. 2014. Military graves from the late Roman necropolis at Slog in Ravna (Timacus Minus). Старинар LXIV: 87-130.

Piletić, D. 1969. Rimski kastrum Ćuprija - Horreum Margi. Vesnik Vojnog muzeja 15: 9-57.

Piletić, D. 1971. Rimsko oružje sa teritorije Gornje Mezije. Vesnik Vojnog muzeja 17: 7-22. Pop-Lazić, S. 2000. Antičke nekropole Singidunuma. Magistarski rad. Univerzitet u Beogradu.

Pop Lazić, S. 2002. Nekropole rimskog Singidunuma. Singidunum 3: 7-100.

Поп-Лазић, С. 2013. Преглед римске војске у Србији током касне антике, у Константин Велики и Милански едикт 313. рађање хришћанства у римским провинцијама на тлу Србије, ур. И. Поповић, Б. Борић-Брешковић. 60-73. Београд: Народни музеј. Popović, D. 1967. Rekognosciranja u Sremu. Arheološki pregled 9: 172-180.

Поповић, И. 1994. Продукција сребра у периоду раног царства: локални производи и импорт, у Античко сребро у Србији, ур. Ивана Поповић. 45-54. Београд: Народни музеј. Поповић, И. 2010. Сакрално-фунерарни комплекс на Магури, у Felix RomulianaГамзиград, ур. Ивана Поповић. 141-158. Београд: Археолошки институт.

Phang, E. S. 2008. Roman military service: Ideologies of Discipline in the Late Republic and Early Principate. Cambridge: University Press.

Radman-Livaja, I. 2010. Lokaliteti civilnog karaktera i slučajni nalazi, u Nalazi rimske vojne opreme u Hrvatskoj, ur. I. Radman-Livaja. 247-262. Zagreb: Arheološki muzej.

Radman-Livaja, I. and Dizdar, M. 2010. Archaeological Traces of the Pannonian Revolt 6-9 AD: Evidence and Conjectures, in IMPERIUM - Varus und seine Zeit, ed. T. Capelle. 47-58. Münster: Aschendorff Verlag.

Рашковић, Д. 2014. Примери касноантичких налаза и налазишта на подручју централне Србије III и IV века. Ниш и Византија XII: 205-218.

Redžić, S. 2008. Vtere Felix Belt Sets on the Territory of Viminacium. Старинар LVIII: $155-162$.

Retief, F. P. and Cilliers, L. 2010. Burial customs the afterlife and the pollution of death in ancient Rome: procedures and paradoxes. Acta Theologica 26(2): 128-146.

Rost, A. and Wilbers-Rost, S. 2013. Besttatungen auf dem schlachtfeld von Kalkriese, in Proceedings of the XVIIth Roman Military Equipment Conference Weapons and Military Equipment in a Funerary Context, eds. M. Sanader, A. Rendić-Miočević, D. Tončinić and I. Radman-Livaja. 37-48. Zagreb: Filozofski fakultet Sveučilišta u Zagrebu, Odsjek za arheologiju; Arheološki muzej u Zagrebu.

Rost, A. and Wilbers-Rost, S. 2017. They fought and died - but were covered with earth only years later: 'Mass graves' on the ancient battlefield of Kalkriese, in Death as a Proccess: Studies in Funerary Archaeology Vol. 12, eds. J, Pearce and J. Weekes. 155-173. Oxford \& Philadelphia: Oxbow Books. 
Santosuosso, A. 1997. Soldiers, Citizens, and the Symbols of War: From Classical Greece to Republican Rome 500-167 B. C. Boulder, Colorado: Westview Press.

Sekelj Ivančan, T. and Tkalčec, T. 2006. Slavensko paljevinsko groblje na položaju Duga ulica 99 u Vinkovcima. Prilozi Instituta za arheologiju u Zagrebu 23: 141-212.

Славнић, М. 1952. Предмети из античких гробова код Кузмина у Срему. Рад војвођанских музеја 1: 60-63.

Срејовић, Д. 1965. Римске некрополе раног царства у Југославији. Старинар ХІІІXIV: 49-84.

Srejović, D. 1993. Roman imperial towns and palaces in Serbia. Belgrade: Serbian Academy of Sciences and Arts.

Срејовић, Д. and Васић, Ч. 1994. Царски маузолеји и консекративни споменици y Felix Romuliani, Гамзиград, Источна Србија. Београд: Српска академија наука и уметности.

Стевановић, М. et al. 1962. Речник српскохрватског књижевног и народног језика (књига II). Београд: Српска академија наука и уметности.

Шпехар, П. 2007. Налази металних делова војног појаса са територије Виминацијума. Ниш и Византија V: 269-290.

Todorović, J. 1968. Kelti u jugoistočnoj Evropi. Beograd: Muzej grada Beograda.

Tomović, M. et al. 2005. Šarkamen (eastern Serbia): A tetrarchic imperial palace, the memorial complex. Belgrade: Archaeological Institute.

Tonc, A. Radman-Livaja, I. and Dizdar, M. 2013. The Warrior Grave from Sveta Trojica near Starigrad Paklenica, in Proceedings of the XVIIth Roman Military Equipment Conference Weapons and Military Equipment in a Funerary Context, eds. M. Sanader, A. Rendić-Miočević, D. Tončinić and I. Radman-Livaja. 245-258. Zagreb: Filozofski fakultet Sveučilišta u Zagrebu, Odsjek za arheologiju; Arheološki muzej u Zagrebu.

Toynbee, J. M. C. 1971. Death and Burial in the Roman World. London: Thames \& Hudson. Валтровић, М. 1885. Римски гробови у облику бунара. Старинар II: 35-45, 69-74. Vasić, С́. 1997. Symbolics of the sacral complex of Romuliana (Gamzigrad), у Уздарје Драгославу Срејовићу: поводом шездесетих година живота од пријатеља, сарадника и ученика, ур. Мирослав Лазић. 443-460. Београд: Центар за археолошка истраживања Филозофског факултета, Универзитета у Београду.

Вујанић, М. et al. 2011. Речник српског језика. Нови Сад: Матица српска.

Vujović, M. 1998. Naoružanje i oprema rimskog vojnika u Gornjoj Meziji i jugoistočnom delu Panonije. Magistarski rad. Univerzitet u Beogradu.

Vujović, M. 2012. Few Contribution on the Late Roman Helmets from Iron Gate. Vesnik Vojnog muzeja 39: 29-43.

Vujović, M. 2013. Roman Weapons and Military Equipment from Singidunum. Vesnik Vojnog muzeja 40: 29-48.

Vujović, M. 2017. Ring Mail from Galerius' Burial Rite at Gamzigrad (Romuliana), in Ante Portam Auream, Studia in honorem proffesoris Aleksandar Jovanović, ed. M. Vujović. 239-250. Belgrade: University of Belgrade, Faculty of Philosophy. 
Вујовић, М. 2019-2020. О једном ,јахачу” из Виминацијума - прилог проучавању римског стрељачког наоружања у Србији. Архаика 7-8: 233-242.

Зотовић, Љ. and Јордовић, Ч. 1990. Viminacvm: некропола “Више гробаља”. Београд: Археолошки институт.

Живић, М. 2003. Felix Romuliana - 50 година одгонетања. Зајечар: Народни музеј Зајечар.

Živić, M. 2007. Catalogue of Small Finds from Excavations outside the Fortified Palace of Romuliana. Старинар LVII: 277-307. 


\title{
Милан Савић
}

Куршумлија

\section{ПРИЛОГ ПРОУЧАВАњУ ГРОБНИХ НАЛАЗА НАОРУЖАЊА И ВОЈНЕ ОПРЕМЕ РИМСКОГ ПЕРИОДА НА ТЕРИТОРИЈИ СРБИЈЕ}

\author{
Кључне речи: гробни налази наоружања, гробни контексти, \\ римски период, погребни ритуал, ратник, војник
}

У приложеном тексту су анализирани налази наоружања и војне опреме у погребним контекстима римског периода на територији Србије. Циљ овог рада је да утврди у ком временском интервалу и на којим налазиштима се на територији Србије током римског периода бележи феномен прилагања војне опреме у погребним контекстима; да покаже до каквих података археологија долази на основу анализе археолошких налаза ове врсте и укаже на комплексност и проблематику тумачења „ратничких” или „војничких" гробова.

Појава наоружања у гробним целинама обично се сматра погребном праксом која није карактеристична за Римљане. Иако није био чест случај да се римски војник сахрани са оружјем и војничком опремом, постоје спорадични примери. Чињеница да су налази наоружања прилагани у гробове током римског периода сама по себи требало би да послужи као разлог за опрезно тумачење „корисника” оружја, односно индивидуа које су са њима сахрањене.

На основу анализе досадашње грађе утврђено је да се овај погребни обичај практиковао током читавог периода римске доминације од 1. до половине 5. века, на простору провинција Доње Паноније, Далмације и Горње Мезије, али не увек са истим интензитетом. Њихова учесталост кроз векове је различита, те стога гробне целине обрађене у овом раду можемо поделити у неколико хронолошких оквира. На првом месту су најстарије хронолошки опредељени гробови из 1. века и они би се могли определити као потенцијални траг аутохтоних популација, које су задржале своје старе погребне обичаје и током римског периода. У том погледу не треба заборавити да су домородачке популације Горње Мезије биле главни извор регрутовања легије IV Flavia и VII Claudia (чак 72\%), које су биле стално стациониране у овој провинцији. Ипак, треба напоменути да се овај релативно висок проценат регрутације односи на 2. век, дакле један век након римског освајања територије провинције Горње Мезије. 
Посебну групу чине етажни гробови (Мала Копашница - Cace) спаљених покојника из периода 2-3. века. Међутим, за сада није могуће са сигурношћу понудити њихово етничко порекло.

Неколико гробних целина са простора данашње Србије издваја се по својој несвакидашњости и отвара нова питања о погребним обичајима римског периода. То су најпре налази наоружања у касноантичкој гробници, с краја 3. века - почетка 4. века, нађеној недалеко од бедема Феликс Ромулијане, међу којима се посебно издваја намерно савијена спата. Она је посебно важна, с обзиром на то да су Келти и Германи практиковали намерно уништавање и савијање наоружања. Као засебна целина издваја се тумул 2 на Магури, недалеко од Феликс Ромулијане, место где је спроведена апотеоза цара Галерија. Налази наоружања пронађени у овом царском фунерарном контексту отварају нова питања на пољу размишљања о гробним налазима наоружања, као погребне праксе која није карактеристична за Римљане.

Неколико покојника из гробних целина анализираних у овом раду највероватније припада ратницима германског порекла. Међу њима су гробови у Врању код Хртковца, Чачку, Понтесу код Трајановог моста, на некрополи „Слог” код Тимакум Минуса, као и гробови 3/2005 и 2/2006 на некрополи IV из времена Сеобе народа у Сингидунуму.

Бројна питања постављена у овом раду траже обавезно повезивање у истраживањима праисторијске и римске археологије, заједничко третирање многих проблема везаних за период успостављања римске власти - прелазни период, али и анализирање гробних целина на територијама које су насељавале германске популације. 